\title{
The mediating role of ethical climate between organizational justice and stress: A CB-SEM analysis
}

\author{
الدور الوسيط للمناخ الأخلاقي بين العدالة التنظيمية والتوتر: تحليل ج ب - سيم
}

Written by: https://orcid.org/0000-0002-7833-7864

\begin{abstract}
The aim of the current study was to investigate the mediating effect of an ethical climate on the relationship between organizational justice (OJ) and workplace stress. The quantitative survey research design was used and cross sectional data was collected. A structured questionnaire was distributed among the nurses working in different healthcare organizations in the Qassim region. There were total 5542 nurses working in different public and private healthcare organizations. Nonprobability convenience sampling technique was used for selecting sample size. Total 510 completed questionnaires were collected back and used in the study for data analysis. For data analysis AMOS-SEM was used. Measurement and structural models were developed and tested in the current study. Reliability and validity were investigated through measurement model, while for hypotheses testing structural model was developed. Findings of the study indicated that scale used in the study was found reliable and valid. Factor loadings, average variance extracted and construct reliability met the threshold level/standard criteria. Structural model also revealed that ethical climate mediated the relationship between organizational justice (OJ) and stress. This is an original work and contribution to the body of knowledge by extending literature on justice, stress and ethical climate. Presence of justice and ethical climate made it possible for employees to better manage their stress.
\end{abstract}

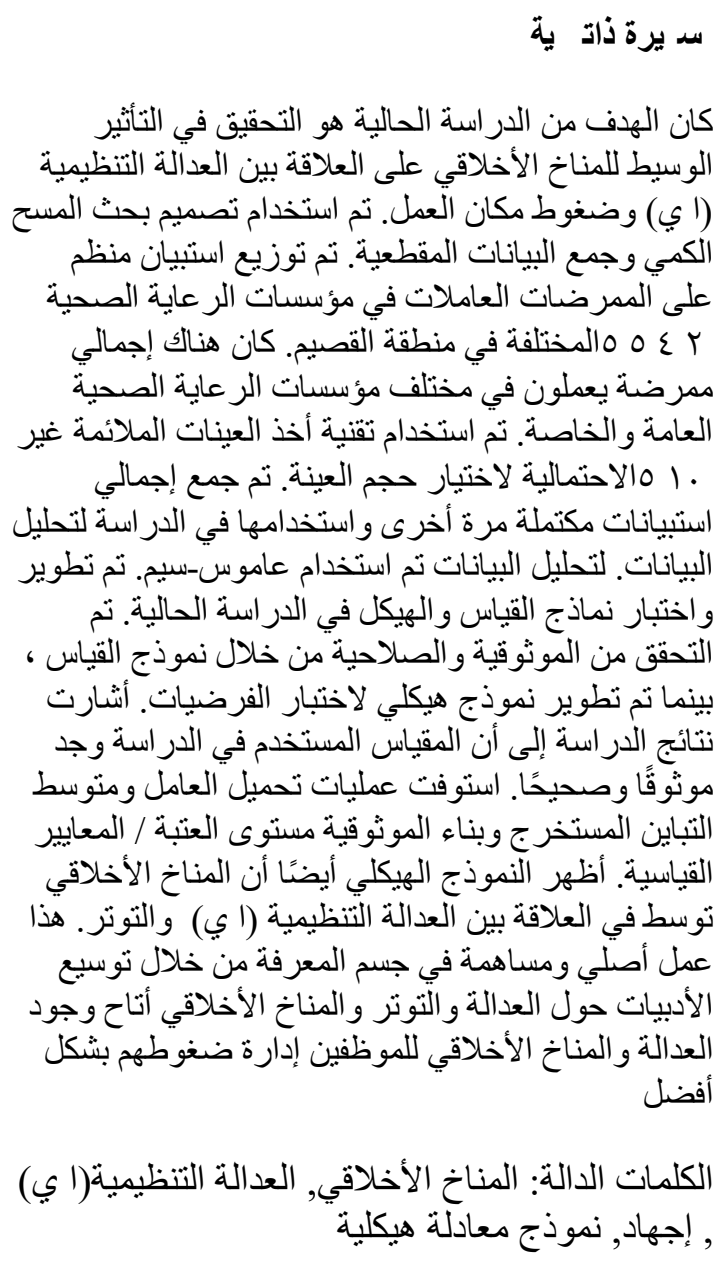

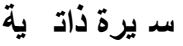

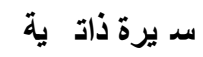$$
\text { كان الهدف من الدراسة الحالية هو التحقيق في التأثير }
$$

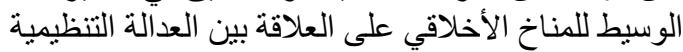

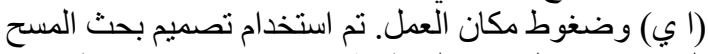

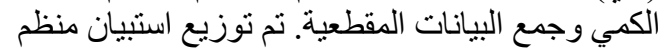

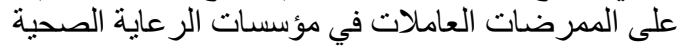

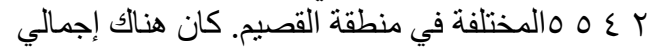

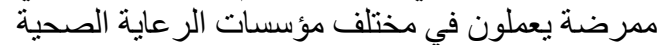

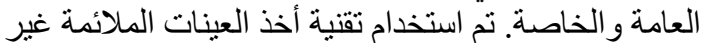

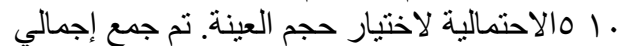

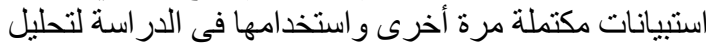

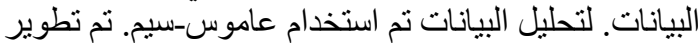

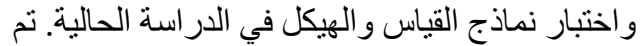

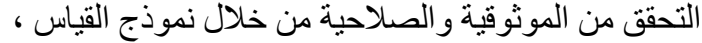

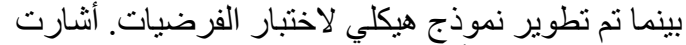

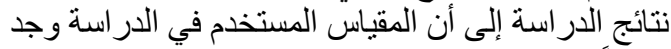

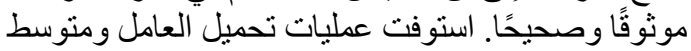

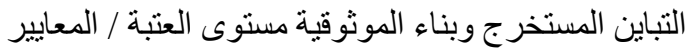

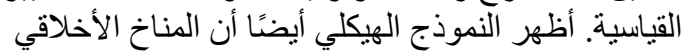

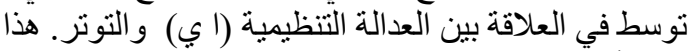

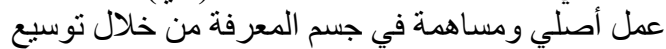

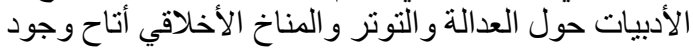

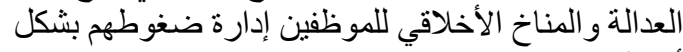$$
\text { أفضل }
$$$$
\text { الكلمات الدالة: المناخ الأخلاقي, العدالة التنظيمية(اي) }
$$$$
\text { , إجهاد, نموذج معادلة هيكلية الأة الاخية }
$$

Key Words: Ethical Climate, Organizational Justice (OJ), Stress, Structural Equation Modeling.

\footnotetext{
${ }^{21}$ Department of Health Administration College of Public Health and Health Informatics Qassim University, Al-Qassim, Al-Bukairyah Kingdom of Saudi Arabia. E-mail: f.alonazy@qu.edu.sa, fahad.albejaidy@yahoo.com
} 


\section{Introduction}

Organizational justice (OJ) significantly contributes towards employees' stress (Sharma and Kumra, 2020). Previous studies has demonstrated that organizational justice, as perception of employees, is significantly related with their level of stress, actions, emotions, feelings, and depression (Cassar \& Buttigieg, 2015). Sharma and Kumra (2020) argued that unequal distribution of resources and unethical behavior is responsible for increasing level of stress among a workforce. There is an uncertainty about organizational justice that how it will contribute to stress? Organizational justice is defined as the perception of employees towards fairness; this perception enhances loyalty, psychological safety, fairness and reduces the concerns of authority power and unequal distribution of resources. Organizational justice significantly predicts commitment, employee engagement, their mental health and stress. It is very important to understand the role of organizational justice. It is essential for organizations to understand employee's innovative work behavior (Shakil, Memon \& Ting, 2021), stress at workplace to increase their performance. Moreover, Islam and Alharthi (2020) explained that ethical climate also plays its crucial role in increasing or decreasing level of stress. Ethical practices especially in health sector are very important for all stakeholders in term of workplace stress. Health professionals work under great pressure and they are already having high level of stress. So, it is very important for organizations to implement and practice ethical climate in order to control negative outcome such as stress. Ethical behavior of top management and organizations increases the volume of inspiration of employees'. The main issue which creates stress among employees are unequal distribution of resources, unethical behavior of top management, and unethical climate which will creates frustration among employees, in addition the promise made by the management to their employees, if these promise are not fulfilled it will also create stress and employees will show resistance, low performance and lack of motivation. Factors which are responsible for low performance, and high stress, anxiety, depression and intention to quit are low wage, tough routine and working hours, poor promotion policies, no recognition, and acknowledgments, less appreciation and bad relationship with supervisor and colleagues (Omar, Salessi, , Vaamonde, \& Urqueaga, 2018). When employees are not paid adequately it will lead to several negative outcomes such as low level of motivation, dissatisfaction, low commitment level, high turnover intentions and stress. The most dominant issue which can increase the level of stress is injustice (Sert, Elci, Uslu \& Sener, 2014).

Over the last two decades organizational justice $(\mathrm{OJ})$ is recognized as a factor that contributes towards employees' mental health issues i.e. stress. The organizational justice $(\mathrm{OJ})$ is significantly related with level of stress. However, there is some gap and something uncertain, not known and overlooked about the potential and capability of organizational justice (OJ) that how OJ as a single predictor could bring variation in mental health issues such as stress, depression and anxiety (Sharma and Kumra, 2020). Hence this study investigates the impact of OJ on stress. Nevertheless researchers investigated the direct effects between OJ and stress, OJ and mental health which show a limited picture of the subject matter (Sharma and Kumra, 2020). In-spite of having practical, theoretical and methodological implications of OJ, researchers have examined directs effects but still indirect effects through mediating mechanism are not well known, this may lead towards the theoretical gap prevails in the literature (Manville et al., 2016; Sharma \&Kumra, 2020). Drawing upon the Social Exchange Theory (SET) (Blau 1964; Sharma and Kumra, 2020; Leventhal, 1980), Adams' Equity theory (Adam, 1965) and Organizational Justice Theory (OJT) Greenberg (1986) has proposed a mediating role of ethical climate on the relationship between OJ and stress. In addition, the Resource Orchestration Theory (ROT) stated that having sufficient resources is not enough for organizations to attain competitive advantage; managerial orchestration and managerial acumen are essential. Efficient use of resources, equal distribution and effective handling of resources is also very important. Therefore it is very important to distribute the resources equally among the employees (Peuscher, 2016). The current study has introduced three component model which is extracted from past literature is the most comprehensive one. Previously, researchers argued that level of stress and engagement of employee in organizations (Memon et al., 2020) depends completely on the resources distributed by the organization's management and treating their workforce in an ethical way; might affect employees' stress, productivity and performance. 
Further, it was also described that management should keep their personal biases and politics out of the organizations and employees should be treated fairly without discrimination, there should be no favoritism, nepotism cynicism and cronyism (Judge \& Colquitt, 2004; Mughal, 2020). It is imperative for organizations and management that they must strictly follow and implement ethical practices, it will increase reputation of the organizations in the eyes of employees, they will feel proud to be part of the organization and also it will create a good image in the eyes of the stakeholders as well (Elsheikh et al., 2018). It is therefore very essential to investigate the relationship between

\section{Literature review}

\section{Organizational Justice (OJ)}

Justice is one of the most important aspects among all cultural values (Moorman, 1991). This provides basis for all right conducts and activities. Society and business organizations must show fairness in all their conducts (Lambert et al., 2020). Jameel, Mahmood and Jwmaa (2020) argued that human beings want to have orderly lives. This is the most important and crucial aspect of individual living in societies. Boyd (2020) wrote a book on organizational justice in which he claimed that organizational justice is very important as senior management could not bring change without the support of employees, so senior management has to reduce inequalities in the organizations. Individuals have developed several ideologies and among all these ideologies job or working in structured organizations has created some ideas, among these ideas organizational justice is most important, inequality and injustice linked to negative perceptions while justice and equality leads to pleasant feeling, emotions and positive outcomes (Ahmad \& Jameel, 2018).

When employees are treated fairly it is called organizational justice (Colquitt et al., 2001). Organizational justice has many dimensions. Fair pay, fair policy of treating employees all falls under organizational justice. According to Green (2005) organizational justice has four dimensions distributive, procedural, interactional and informational justice. According to Bornstein and Dietrich (2007), the concept of organizational justice is full of different flavors. But most studied are two dimensions distributive and procedural justice as other two dimensions are overlooked so in this study researcher has included other two dimensions also in order to organizational justice (OJ) and stress with mediating role of ethical climate (Islam \&Alharthi, 2020). In the current study, researcher has investigated the mediating role of ethical climate on the relationship between organizational justice (distributive, procedural, informational and interpersonal justices) and stress. The current study thus clearly attempts to answer the following research questions:

RQ1: Whether Organizational justice (OJ) and ethical climate accounts for reducing level of stress among employees?

RQ2: Does ethical climate mediates between organizational justice (OJ) and stress?

fill the research gap (Sert et al., 2014; Sharma \&Kumra, 2020).

\section{Distributive Justice}

According to Kassim et al., (2018) distributive justice is to provide fair proportions of benefits to all employees. These benefits are allocated on the basis of performance of employees rather on personal likes, dislikes, or favoritism. Management should be fair in providing adequate promotion policies, working shifts, appraisal, salaries and bonuses. Moreover, Qureshi et al (2017) stated that there is difference in equity and equality. Equality implies all employees are treated and handled same. On the other hand equity means output is determined by employees' input and initiatives. Concept of organizational justice and distributive justice are based on the social exchange theory (Lambert et al., 2007). This concept was first introduced by Greenberg (1986). In this concept, each section is linked with some other valuable sections. For example, employees provide their efforts, potential, skills, experience, and knowledge as input to their organizations and in return they receive salary, benefits, etc. when employees compare their efforts and input with the efforts, inputs of their coworkers and if they found some difference in the rewards received by them and their coworkers, it disappoints them and results in low performance and productivity.

\section{Procedural Justice}

Jameel et al., (2020) claimed that how the outcomes are allocated, not the outcomes themselves, refers to procedural justice. Procedural justice also means that methods and procedures used in the organizations are fair and just. These procedures are used for attaining some targets and objectives. It is also claimed 
that right results could be achieved by unfair means but it is unethical way, and it will create negative perception. Majority of the employees have the point of view that procedures and methods followed for achieving targets should be accurate, open and just, and they don't care about the results (Sharma \& Kumra, 2020).Fairness in judgment and fair decision making is called procedural justice (Greenberg, 1986; Sert et al., 2014).In procedural justice attention is given to the fairness of process which administration adopted to punish or given rewards to their employees (Greenberg, 1986). According to Bornstein and Dietrich, (2007)if employees feel that process was not fair then negative outcomes will come such as high dissatisfaction, low performance, less productivity, high absenteeism etc. According to Greenberg (2005) any organization wants to follow fair procedural justice must adopt five rules, one voice, mean employees must be given voice in process then they feel the process was fair, second all rules must be same for all employees, third information used in the process must be correct. Fourth, if false information is used then employees must be given opportunity to be heard to correct it (Greenberg, 2004). Last, there must be no biasness; process should be bias free.

\section{Interactional Justice}

In 1987, interactional justice was not part of the organizational justice, but later Greenberg (1990) and Cropanzano and Greenberg (1997) added interactional justice as a determinant of organizational justice. They divided interactional justice into informational justice and interpersonal justice. First one is related to use of correct information and second interpersonal relationship. For example, respect, credibility, dignity etc. According to Roy, Bastounis, and Minibas-Poussard (2012) interactional justice is more dominant and prominent facet because components of interactional justice are more active in daily routine at work place as compared to distributive and procedural justice. When employees perceived low level of interactional justice it will come out with negative outcomes among employees, like stress, depression, anxiety etc. According to Jameel et al (2020) doing business by an appropriate way is called interactional justice. Furthermore, they have also highlighted the six features of interactional justice such as; decision making, behavioral freedoms, respect for human rights, kindness, avoiding disappointments and sincerity. The first feature is related with interactional justice while remaining five are therapy elements.

\section{Organizational Justice (OJ) and Employees Workplace Stress}

Fulfillment of needs over capacities is called stress. In stress, emotions play important role because they motivate psychological change in human mind (Fox et al., 2001; Cooper \& Robertson, 1989). This stress is a threat to human especially workers. This stress is linked with mental breakdown, and physical condition of workers (Lee, Lee, Gillen \& Krause, 2014;Kumasey et al., 2017).Employees have high level of stress, burnout, emotional exhaustion, depersonalization and no personal achievement due to insufficient facilities. High level of stress leads to negative outcomes like high turnover and high burnout (Rahman et al., 2016).

According to Hart and Cooper (2001) unhappy and unpleasant emotions are not in control of employees. They also explained that work experience often increase stress which is called stressor while impact of stress on employee's condition is called strain (Joksimovic et al, 2002).There are different kinds of stressors like physical environment of workplace, role of employee, job demands etc. According to Judge and Colquitt (2004) there are other interpersonal stressors. One is interpersonal conflict, means rude behavior of colleagues towards a given employee. Other stressors are lack of information, leadership, no social support, bad relationship with seniors; all these are related to informational and interpersonal facets of organizational justice (Al-kilani, 2017; Kassim et al., 2018).

Marshall and Cooper (1979) introduced a model they said that participation and autonomy create problems with procedural justice. They argued that when participation and autonomy is lacking in supervisor-subordinate relationship it would create problems and increase stress among employees. Relationship between organizational justice and stress has some theoretical reasons and basis. Thibaut and Walker (1975) introduced instrumental model and claimed that procedural justice is valuable to bring long term outcomes. Uncertainty theory of management suggests that all kinds of justice are valuable because on basis of information provided we can navigate the uncertain work situations (Boyd, 2020; Lind \& Van Den Bos, 2002).

Equity theory suggested the relationship between distributive justice and stress when employees compare their inputs with output they received 
and compared with their colleagues (Judge \& Colquitt, 2004). Justice has the ability to reduce stress among employees. Equity theory has the mechanism to reduce stress and the mechanism may be used by adding mediating variables (Greenberg, 1984; Sharma and Kumra, 2020). According to Folger (1993) cognition theory argued that procedural injustice can lead to various form of stress. According to the Uncertainty Management theory unfairness leads to stress. There are several studies which have linked justice and its facets with stress but not all justice facets were used together in one study. Studies have used all four facets of justice but used work family conflict (WFC) as a mediator (Judge \& Colquitt, 2004). Tepper (2000) conducted a study and used three dimensions of justice. But no such study has used all dimensions of justice with stress in organizations. On the basis of this theoretical and empirical ground we have developed the hypotheses. Our hypotheses are aligned with hypotheses of Judge and Colquitt (2004) contributed in their article by extending and tested four factors, this study also added four factor of OJ. Literature explained that high level of injustice and unethical practices results in high level of stress. It means that relationship between organizational justice is negatively related with stress and relationship between ethical climate and stress is also negative (Jameel et al., 2020).

\section{Mediating Role of Ethical Climate with Organizational Justice (OJ)and Stress}

This concept of ethical climate was first introduced by Victor and Cullen (1988). They explained that organizations are like tribes. Tribes have set their own norms, values, culture, language, way of celebration, success stories etc. Same way organizations have their own values, culture, and way of doing work. This ethical climate also helps organizations in ethical decision making (Kancharla \& Dadhich, 2020; Islam \& Alharthi, 2020). It also helps to answer what shall we do and how shall we do? (Sert et al., 2014). Ethical and unethical climate and unethical decision making is perception of employees towards values norms or organizations towards their employees (Mulki, Jaramillo \& Locander, 2008; Mitonga-Monga, 2020). Attitudinal theory explained that evaluation by individuals lead to behavioral outcomes (Ajzen, 2001; Tariq, Ali, Mughal \& Ali, 2018). Positive evaluation would results in low level of injustice and low level of stress among employees. According to Mulki et al., (2006) those employees who are working in ethical climate their attitude is seen positive, they have more trust on their management (Valentine \& Godkin., 2016).

Victor and Cullen (1988) have introduced three aspects of ethical climate egoism, benevolence and principle. They also introduced three level of ethical climate one is local, cosmopolitan and individual. Local refers to organizations, cosmopolitan refers to society and third one is related to personal belief (Kuenzi, Mayer \& Greenbaum, 2019). Also Victor and Cullen (1988) introduced five dimensions of ethical climate i.e. caring, independent, law and code, instrumental and rules. These dimensions control behavior of employees because employees align their behavior with values of organizations (Houghton et al., 2016; Mulki et al., 2008). Likewise, Jaramillo et al., (2013) reported significant impact of ethical climate at work place stress. When employees go through ethical challenges and difficulties then it would results in increase in stress (Ilyas et al, 2020). This concept got support from study findings of Briggs et al., (2012) reported that there is direct impact of ethical climate on stress. Sert et al., (2014) conducted on ethical climate organizational justice and stress and suggested to use ethical climate as mediator but in Sert et al., (2014) used ethical climate as independent variable. So in this study ethical climate was taken as mediator between organizational justice and stress. Also Sert et al., (2014) reported the negative relationship between ethical climate and stress. There is positive relationship between organizational justice and ethical climate (Moslehpour, Altantsetseg, Mou and Wong, 2018). There are certain issues and recommendation in mediation analysis for this purpose the existing study seeks guidance on issues and recommendation in mediation analysis, explained by (Memon, Cheah, Ramayah, Ting, \& Chuah, 2018).

$\mathrm{H} 1_{\mathrm{a}}$ : Ethical climate has indirect effect on organizational justice and stress. 


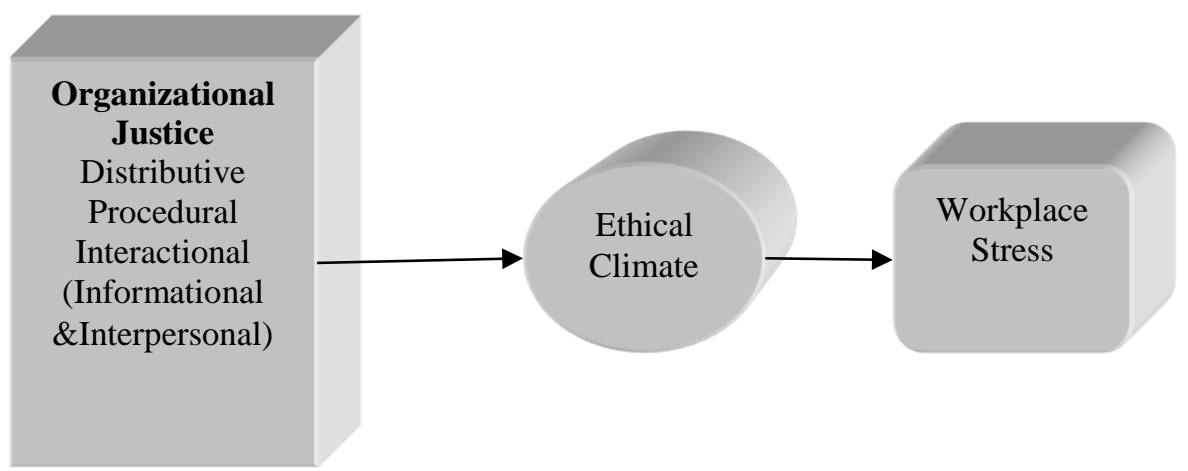

Figure 1. Framework of Study Source: Sert et al, (2014)

\section{Research Methods}

\section{Population and Sampling}

Cross sectional study was conducted. Population of the study was all the nurses from all healthcare institutions in the Qassim region. Total numbers of nurses in the Qassim región was 5542 as identified by Takroni et al., (2018). A convenience sampling strategy was used, researcher has distributed total 600 questionnaires and 510 complete questionnaires were returned and used in the analysis. Yielding the response rate of $85 \%$. There are different instruments developed by different scholars, to measure organizational justice Niehoff and Moorman (1993) has validated and reported 20 items scale for OJ, similarly scale of ethical climate was developed by Schwepker, (2001) and work related stress was developed by Keller (1984). But all these scales were used and validated by Sert et al., (2014) so researcher adopted these scales from Sert et al., (2014). Regarding the scales, the Organizational justice has four facets each having five items so total 20 items was used for measuring organizational justice (OJ), five for stress and five for ethical climate. Cover letter along with questionnaire was given to all the respondents and three to four days were given to each participant for filling the form correctly and honestly. This study was conducted in December 2019 and January 2020.

\section{Data Analysis}

SPSS version 21 was used for getting results related with descriptive statistics such as demographic information mean, standard deviation, while correlation was run to test hypothesis one, AMOS-SEM was used for developing measurement and structural model and hypotheses number 2 was also investigated in AMOS-SEM. Common method bias using Herman single factor analysis was done and found that there was no issue of common methods biasness. Results of Herman single factor analysis revealed that total variance of $49 \%$ which is less than $50 \%$ so researcher has assumed that this data is free from common method bias or common method variance. Researcher can proceed for further analysis.

\section{Results}

Table 1.

Socio Demographic Information of the Participants.

\begin{tabular}{llll}
\hline Socio Demo Variable & Category & N & \% \\
\hline Gender & Male & 185 & 36.27 \\
\multirow{3}{*}{ Nationality } & Female & 325 & 63.73 \\
& Saudi & 100 & 19.60 \\
& Pakistan & 135 & 26.47 \\
& Philippines & 235 & 46.07 \\
& India & 25 & 4.90 \\
Marital Status & Indonesia & 15 & 2.941 \\
& Married & 300 & 58.82 \\
\hline
\end{tabular}

Source: This Table1 has been taken from SPSS25 version during Data Analysis. 
Results indicated that most of the employees were females participated in this survey i.e. 325 $(63.73 \%)$ followed by their male counterparts i.e. $185,(36.27 \%)$. Further results indicated that there were 100 employees holding Saudi nationality i.e. $19.6 \%$ and 135 employees belong to Pakistan i.e. $26.47 \%$, Philippines 235 i.e. $46.07 \%$ India 25 and $4.9 \%$ while Indonesia 15 , $2.941 \%$. 300 employees were married and 210 were un-married i.e. $58.82 \%$ and $41.17 \%$. See Table 1.

Table 2.

Mean Scores.

\begin{tabular}{lll}
\hline Variable & Mean & S.D \\
\hline Distributive & 5.52 & 0.95 \\
Procedural & 5.50 & 1.01 \\
Informational & 5.46 & 0.97 \\
Interpersonal & 5.43 & 0.98 \\
Ethical Climate & 5.41 & 0.87 \\
Stress & 5.40 & 0.94 \\
\hline
\end{tabular}

Source: This Table2has been taken by author of this study from SPSS25 version during Data Analysis.

Table 2 results revealed that most dominant factor among the variables is distributive justice among employees $\mathrm{M}=5.52$, $\mathrm{S} . \mathrm{D}=0.95$. Followed by procedural justice $\mathrm{M}=5.50$, $\mathrm{S} . \mathrm{D}=1.01$ it means that these two areas are very important among employees. Further this means that employees are very much satisfied from the distribution of resources and procedures adopted by organizations. Another facet of organizational justice i.e. informational justice and interpersonal justice, from the results it is evident that for informational justice $\mathrm{M}=5.46$, $\mathrm{S} . \mathrm{D}=0.97$, for interpersonal justice $\mathrm{M}=5.43$, S.D=0.98 means that employees are also satisfied from these two aspects of organizational justice moreover, this means that distribution and procedural justice are high in standards as compared to dimensions of interactional justice. Then mean score of ethical climate is $\mathrm{M}=5.41$, $\mathrm{S} . \mathrm{D}=0.87$, and work place stress is $M=5.40, S . D=0.94$. It means that level of stress is lowest among employees because of fair policies and fair distribution of resources, and employees are working in stress free environment seeTable 2.

Table 3.

Measurement Model.

\begin{tabular}{|c|c|c|c|c|c|c|c|}
\hline \multirow{2}{*}{ Variables } & \multirow{2}{*}{ Items } & \multirow{2}{*}{ M } & \multirow{2}{*}{ SD } & \multirow{2}{*}{ Loadings } & \multicolumn{2}{|c|}{ Convergent Validity } & \multirow{2}{*}{$\begin{array}{l}\text { Cronbach } \\
\boldsymbol{\alpha}\end{array}$} \\
\hline & & & & & $\mathrm{CR}$ & AVE & \\
\hline \multirow{6}{*}{ Distributive Justice } & DJ1 & 5.65 & 1.27 & 0.57 & & & \multirow{6}{*}{0.831} \\
\hline & DJ2 & 5.51 & 1.20 & 0.63 & & & \\
\hline & DJ3 & 5.45 & 1.19 & 0.73 & & & \\
\hline & DJ4 & 5.48 & 1.24 & 0.79 & 0.831 & 0.501 & \\
\hline & DJ5 & 5.54 & 1.28 & 0.79 & & & \\
\hline & PJ1 & 5.48 & 1.23 & 0.77 & & & \\
\hline \multirow{4}{*}{ Procedural Justice } & $\mathrm{PJ} 2$ & 5.48 & 1.21 & 0.80 & 0.891 & 0.621 & \multirow{4}{*}{0.891} \\
\hline & PJ3 & 5.54 & 1.23 & 0.79 & & & \\
\hline & PJ4 & 5.52 & 1.19 & 0.78 & & & \\
\hline & PJ5 & 5.52 & 1.22 & 0.80 & & & \\
\hline \multirow{5}{*}{ Informational J } & IFJ1 & 5.51 & 1.19 & 0.75 & 0.868 & 0.569 & \multirow{5}{*}{0.868} \\
\hline & IFJ2 & 5.54 & 1.26 & 0.78 & & & \\
\hline & IFJ3 & 5.45 & 1.18 & 0.73 & & & \\
\hline & IFJ4 & 5.39 & 1.18 & 0.76 & & & \\
\hline & IFJ5 & 5.45 & 1.18 & 0.75 & & & \\
\hline \multirow{5}{*}{ Interpersonal Just } & IPJ1 & 5.48 & 1.22 & 0.76 & 0.868 & 0.569 & \multirow{5}{*}{0.869} \\
\hline & IPJ2 & 5.49 & 1.20 & 0.78 & & & \\
\hline & IPJ3 & 5.37 & 1.22 & 0.76 & & & \\
\hline & IPJ4 & 5.44 & 1.20 & 0.75 & & & \\
\hline & IPJ5 & 5.37 & 1.19 & 0.72 & & & \\
\hline \multirow{2}{*}{ Ethical Climate } & $\mathrm{EC} 1$ & 5.43 & 1.14 & 0.70 & & & \multirow[b]{2}{*}{0.834} \\
\hline & $\mathrm{EC} 2$ & 5.46 & 1.08 & 0.68 & 0.823 & 0.484 & \\
\hline
\end{tabular}




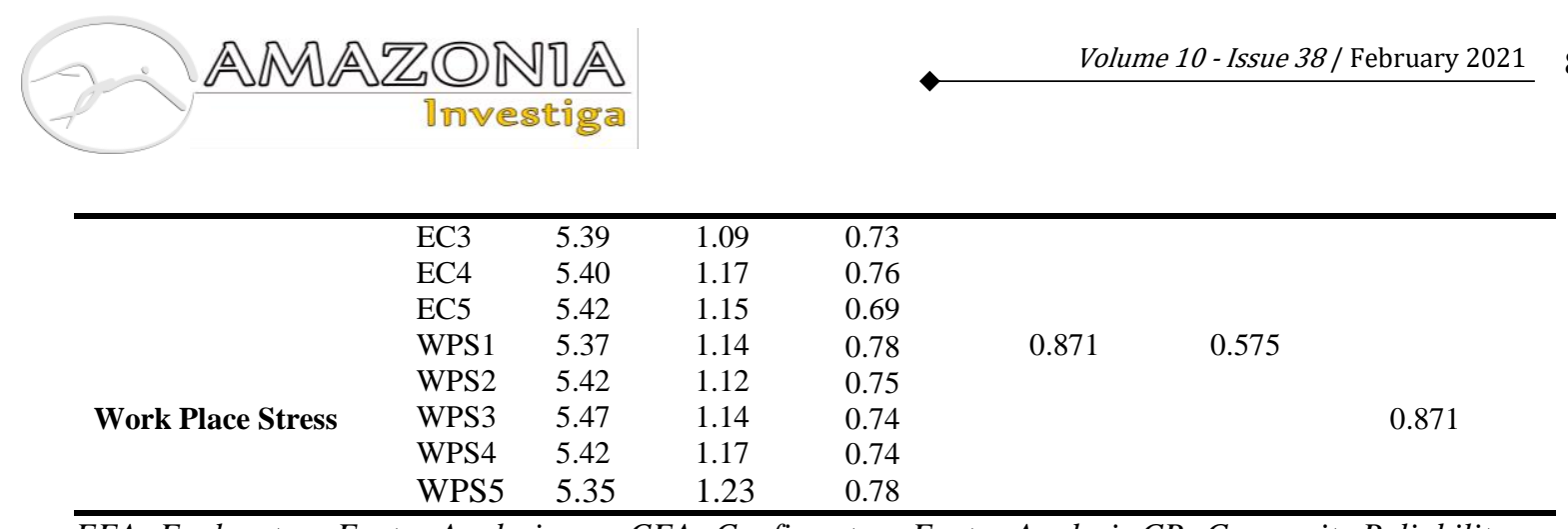

EFA: Exploratory Factor Analysis; $\quad$ CFA: Confirmatory Factor Analysis CR: Composite Reliability $C V$ : convergent Validity; AVE: Average Variance Extracted;

Mean, standard deviation, confirmatory factor analysis (CFA), and Cronbach alpha test are important for researchers to report reliability and validity of scales. These tests are used to refine the scales if any item found problematic. To get best fit model there are certain criteria given by (Field, 2013; Hair et al., 2014; Mukhezakule \& Tefera, 2019). Further for reliability cronbach alpha test value must be 0.70 are greater. From the above Table 3 mean, standard deviation of all the items for distributive justice, procedural justice, informational justice, interpersonal justice, ethical climate and work place stress are presented. It is evident that mean scores and standard deviation of all the items are very close to each other this means that there is homogeneity between responses of all respondents and they all are on same page having same opinion about above mentioned variables. Second results of CFA are presented in Table 3. It is revealed that all the items of distributive justice, procedural justice, informational justice, interpersonal justice, ethical climate and work place stress are greater than 0.50. In CFA goodness of fit index is checked by Chi-square, DF degree of freedom, GFI= goodness of fit index, $\mathrm{CFI}=$ comparative fit index. $\mathrm{RFI}=$ relative fit index and RMSEA= root mean square error of approximation. All these indices met the criteria given by hair et al., (2017) and thus scale is considered valid. RMSEA $=0.044$, CFI $=0.958$, RFI $=0.913$, Chi-Square $=2.008$ also see Figures 2 , Third results of reliability test cronbach alpha are presented in last column. Reliabilities and validities of these scales were checked. According to Hair et al., (2017) the value of composite reliability must be higher than 0.7 average variance extracted must be greater than 0.5 . In the above Table 3 all the composite reliabilities $(\mathrm{CR})$ values and average variance extracted (AVE) values are greater than cut off level, furthermore, discriminant validity is investigated and reported by taking HTMT ratios see table-4 so all the scales are considered reliable and valid. This means that all variables distributive justice, procedural justice, informational justice, interpersonal justice, ethical climate and work place stress and their reliabilities are accepted and scales used in this study are reliable and valid so researcher can proceed for further analysis. 


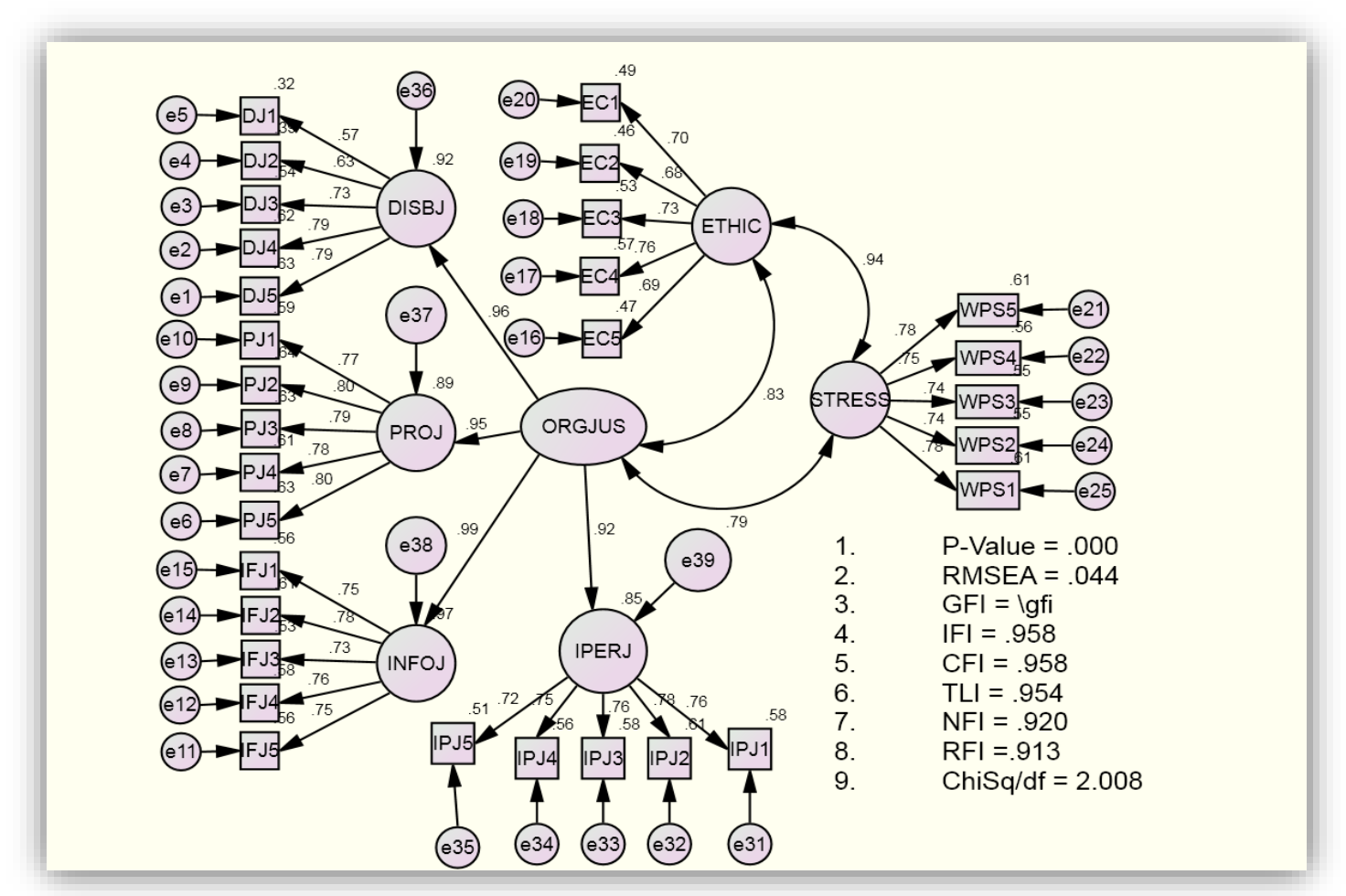

Figure 2. Measurement Model AMOS-SEM.

Source: This figure-2 has been taken from AMOS-SEM during Data Analysis, RMSEA=root mean square error of approximation, GFI-goodness of fit index, $I F I=$ incremental fit index, CFI=Comparative fit index, $T L I=$ Tuker lewis index, NFI= normed fit index, RFI=relative fit index

Table 4.

HTMT Ratio for Discriminant Validity.

\begin{tabular}{|c|c|c|c|c|c|c|}
\hline & 1 & 2 & 3 & 4 & 5 & 6 \\
\hline \multicolumn{7}{|l|}{ Distributive Justice } \\
\hline Ethical climate & 0.762 & & & & & \\
\hline Informational Justice & 0.925 & 0.813 & & & & \\
\hline Interpersonal Justice & 0.830 & 0.893 & 0.934 & & & \\
\hline Procedural Justice & 0.962 & 0.759 & 0.926 & 0.818 & & \\
\hline Workplace stress & 0.752 & 0.944 & 0.769 & 0.778 & 0.728 & \\
\hline
\end{tabular}

This study has used hetero-trait mono-trait ratio (HTMT) for discriminant validity. The threshold value for HTMT ratio is 0.85 (Kline, 2011) and according to Teo et al., (2008) it should not exceed 0.90. But Hair et al., (2017) HTMT ratio should be significantly differ from 1 . Above
Table 4 explained that all constructs have passed the HTMT criteria suggested by Hair et al (2017).

$\mathbf{H}_{1 \mathbf{a}}$ : Ethical climate has indirect effect on Organizational justice (OJ) and stress. 


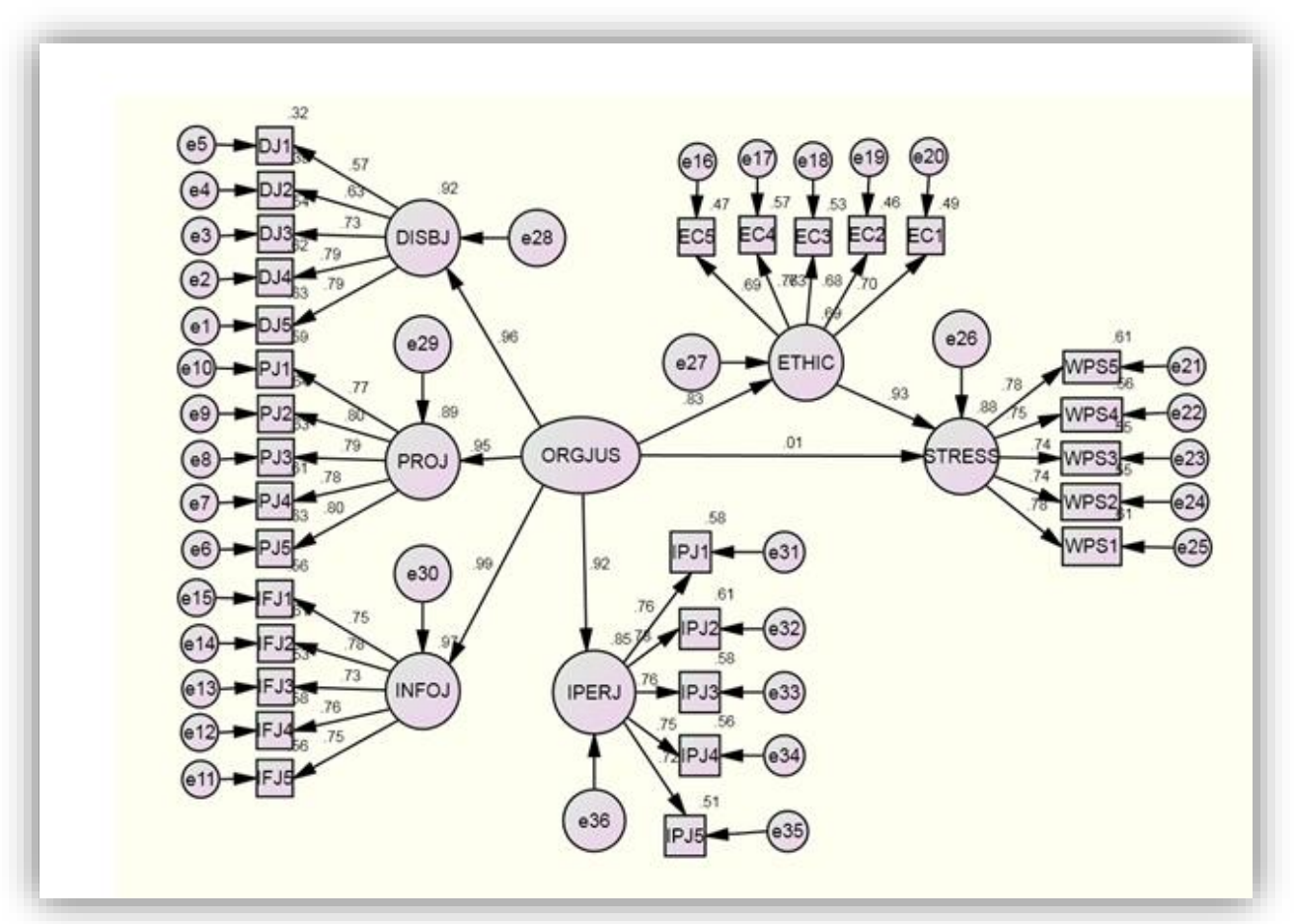

Figure 3. Structural Model AMOS-SEM.

Source: This figure 3 has been taken from AMOS-SEM during Data Analysis

Table 5.

$H_{1 a}$ : Testing of Mediation Hypothesis (Indirect effect)

\begin{tabular}{llllllllll}
\hline Direct Effects & Estimate & S.E & C.R & $p$ & Indirect Effects & $\beta$ & L(BC) & U(BC) & $p$ \\
\hline OJ $\rightarrow$ Ethics & 0.663 & 0.045 & 14.890 & 0.000 & & & & & \\
OJ $\rightarrow$ STRESS & 0.010 & 0.070 & 0.145 & 0.885 & OJ $\rightarrow$ EC $\rightarrow$ Stress & 0.747 & 0.599 & 0.963 & 0.001 \\
Ethics $\rightarrow$ STRESS & 1.127 & 0.113 & 10.017 & 0.000 & & & & & \\
\hline$B=$
\end{tabular}

$B=$ beta; S.E; Standard Error; C.R: Critical Ratio; P: significant value; ${ }^{* * *} p<0.01 ; * * p<0.05: L(B C)$ and $U(B C)$; Lower and Upper Bounds; OJ= Organizational Justice

Structural equation modeling was used to test the mediation hypothesis. Table 5and Figure 3 results indicated the different path of mediation. Path (a) is about organizational justice and ethical climate from results it is revealed that $\beta=0.663, p<0.01$, path $\mathrm{c}$ i.e. direct path between predictor OJ and criterion stress is $\beta=0.010$, p $>0.05$ is not significant, while path $b$ mediator and criterion i.e. ethical climate and work place stress $\beta=1.127, p<0.01$ is significant. Indirect effect is also presented in the table-5.It was found that indirect effect is significant with beta value 0.747 and $p<0.05$, indicated that ethical climate mediated between organizational justice and workplace stress. The findings of the current study are in line with previous findings of Rasool, Wang, Zhang \& Samma (2020), reported the indirect effects on workplace stress. Moreover, the findings of the current study got support and aligned with results of Sharma and
Kumra (2020) reported the indirect and mediating effects on organizational justice and stress of employees, and stated that it has significant impact on mental health of employees. The findings of the current study are also in agreement with findings of Islam and Alharthi (2020). So from the following discussion it is concluded that ethical climate has indirect effect on relationship between organizational justice and stress. So on basis of above results H1a is accepted.

\section{Discussion}

The aim of this study was to investigate mediating roles of ethical climate on the relationship between organizational justice (OJ) and stress. For this purpose two hypotheses were developed. First hypothesis was to find the relationship between predictors and criterions 
and second was to test mediating effects of ethical climate between justice and stress. It was found that all the predictors and criterion variables were significant and correlated. This implies that justice and ethical practices could be useful in reducing the level of stress among employees, while inequality and unethical behavior and practices would increase the stress among employees. Employees compare their benefits and other facilities with their counterparts if they found it unequal and unjust it will create frustration, anxiety, depression, stress and employees would show resistance. Therefore, it is imperative for the management of the organizations to do ethical practices and keep their personal biases and politics out of the organizations. Just behavior and ethical climate, once established in the organizations, would lead towards enhanced employees' productivity, they will feel valued member of the organizations, and would proud to be part of the organization which is considered ethical in dealing with its employees. Results of the first hypotheses are in line with findings of Jameel et al, (2020) who found significant relationship between predictors and criterions, similarly Ahmad and Jameel (2018) also reported significant association between organizational justice (OJ) and stress. In addition, Sharma and Kumra (2020) also found significant relationship between organizational justice and stress. So hypotheses one was accepted. In the current study, mediating roles of ethical climate i.e. indirect effects were also investigated. It was found that the ethical climate mediates between organizational justice and workplace stress. This means that ethical climate has significant role. The findings recommended that ethical climate is a strong motivator to reduce the level of stress. Organizations need to establish ethical practices and implement and develop ethical climate at workplace. The results of the current study got support from findings of Rasool et al, (2020) who conducted a study in hospitals, and reported indirect effects on occupational stress. Similarly Boyd (2020) also claimed that no organization could achieve its targets until and unless all employees are treated fairly. From the above discussion it is concluded that ethical climate and justice are very crucial and they are responsible for level of stress. Ethical behavior and justice could reduce stress. The findings of the current study are also in line with other studies such as Elsheikh et al., (2018); Searle, \& Auton, (2015); Tuckey, Searle, Boyd, Winefield \& Winefield (2014); Bakker \& Sanz-Vergel (2013); Tadić, Bakker, \& Oerlemans (2015); Long \& Ning (2015); Lind and Van den Bos's (2002); Jaramillo et al., (2006), Mulki et al., (2006). On the basis of above discussion both hypotheses one and two are substantiated

\section{Conclusion}

Justice and ethics could play their positive role in the organizations and help the organizations to reduce the level of stress among their employees. If there are unethical practices prevails in the organizations and there is injustice, it would create frustration, anxiety, depression and stress among employees. When employees perceive that principles of justice are not applied and there are low levels of ethics, it could leads towards high level of absenteeism, stress and low performance. That is why it is imperative for management to implement ethical practices and provide justice while distributing resources and benefits, procedures for making decisions should be same for all employees, furthermore, management must keep good interpersonal relationship with all level of employees. By doing so organizations could attain low level of stress, anxiety, frustration and depression among their talented and hard working employees. Moreover, talented and hard working employees will be retained for longer period of time. Employees will feel proud to be part of ethical organizations. This study has extended the body of knowledge through lens of social exchange theory, resource orchestration theory, organizational justice and equity theory. From the findings of the current study it has been concluded that managers and professionals should strictly follow ethical practices in order to retain their talented and hardworking workforce.

\section{Practical Implications}

The current study has some practical implications for health practitioners; organizations must arrange healthy activities for their employees. It could be helpful to reduce the level of stress, depression and anxiety. Managers who are practicing unethical behavior and responsible for not distributing the resources equally must be identified and discouraged. Training like stress management, personality development, time and relationship management should be arranged so that employees would be able to handle these complex situations. Managers' must consider their employees as assets of the organizations and should deal with them gently, politely and in a civilized way. Top level management should encourage ethical climate, positive work environment and coordination among employees it will reduce insomnia, headaches, depression and stress (Clarke, 2012; Wood, \& Michaelides, 2016; 
Prem et al., 2018; Bergami \& Morandin, 2019; Rasool et al, 2020).

\section{Limitations and Future Research Directions}

The current study has contributions, few limitations and recommendations for future researchers as well. Respondents belong to health profession which might limit the generalization of the conclusions and results. One should be cautious while generalizing the results to other sectors. Future studies may apply this model in different public and private sectors and in different geographical regions. Second, the data collected and analyzed in the current study was crosssectional, it is therefore recommended for future researchers that longitudinal data along with qualitative data might provide in depth understanding of the subject area. Third, the current study has collected the data from nurses, it is recommended that future researchers may collect the data from nurses and doctors, or hospital administrators and can perform MGA multi group analysis for better understanding of the subject matter. Fourth, the current study has used ethical climate as mediator it is recommended that occupational burnout, well being and workplace violence might be used as mediator in future studies. Safety management psychological capital may be used as moderators. Fifth, non-probability convenience sampling was used for selecting sampling size; future studies may use random sampling techniques that would be more appropriate strategy for generalizing the research findings. Sixth, there is lack of research on HRM in Asian context (Memon, Salleh, Mirza, Cheah, Ting, Ahmad, Tariq, 2020; Memon, Ting, Cheah, Thurasamy, Chuah, \& Cham, 2019) especially Middle Eastern perspective, the reason behind this notion that HRM in Asia is not homogenous therefore it would be better if future studies may test the current model by adding employee/work engagement and turnover intention (Memon, Salleh, Mirza, Jun-Hwa, Ting, and Ahmed, 2019).

Acknowledgement: Author want to thank all respondents participated in this study.

Conflict of Interest: There is no competing interest. No funding for this study

\section{References}

Adams, J.S. (1965). Inequality in social exchange". Advanced Experimental Psychology, Vol 62, 335-343.

Ahmad, M. A. A., \& Jameel, A. S. (2018). Factors affecting on job satisfaction among academic staff. Polytechnic Journal, 8(2), 119-128.
Ajzen, I. (2001). Nature and Operation of Attitudes. Annual review of psychology. 52, 27-58. 10.1146/annurev.psych.52.1.27.

Al-Kilani, M. H. (2017). The influence of organizational justice on intention to leave: Examining the mediating role of organizational commitment and job satisfaction. Journal of Management and Strategy, 8(1), 18-27.

Bakker, A. B. \& Sanz-Vergel, A. I. (2013). Weekly work engagement and flourishing: The role of hindrance and challenge job demands. Journal of Vocational Behavior, 83(3), 397-409. Bergami, M. and Morandin, G. (2019), "Relationship between perceived justice and identification", Employee Relations, Vol. 41 (1), pp. 176-192.https://doi.org/10.1108/ER-092017-0210

Blau, P. (1964). Power and Exchange in Social Life. New York: John Wiley \& Sons.

Bornstein, B. H., \& Dietrich, H. (2007). Fair procedures, yes. But we dare not lose sight of fair outcomes. Court Review; The Journal of American Judges Association, 44, 1/2, p. 72, 74.

Boyd, D. R. (2020) Thirst for Justice: A Novel Paperback. Toronto: ECW Press.

Briggs, E., Jaramillo, F., and Weeks, W. A. (2012). The influences of ethical climate and organization identity comparisons on salespeople and their job performance. Journal of Personal Selling and Sales Management, 32(4), 421-436. Cassar, V. and Buttigieg, S.C. (2015). Psychological contract breach, organizational justice and emotional well-being. Personnel Review, Vol. 44(2), pp. 217-235.

Clarke, N. (2012) Evaluating Leadership Training and Development: A Levels - of Analysis Perspective. Human Resource Development Quarterly, 23(4), 441-460, https://doi.org/10.1002/hrdq.21146

Colquitt, J.A., Conlon, D.E., Wesson, M.J., Porter, O.L.H., \& Ng, K.Y. (2001). Justice at the millennium: A Meta-analytic review of 25 years of organizational justice research. Journal of Applied Psychology, 86(3), 425-445.

Cooper, C.L and Robertson, I. T. (eds.) (1989). International Review of Industrial and Organizational Psychology 1988: 1988, Chichester, New York, etc: Wiley. 337 pages. Organization Studies, 10(3), 449-449. Doi: 10.1177/017084068901000317

Cropanzano, R. and Greenberg, J. (1997). Progress in organizational justice: Tunneling through the maze. In C. L. Cooper \& I. T. Robertson (Eds.), International review of industrial and organizational psychology (Vol. 12, pp. 317-372). Oxford, England: Wiley 
Elsheikh, A.S., Alqurashi, A.M., Wahba, M.A., \& Hodhod, T.E. (2018). Healthcare workforce in Saudi Arabia under Saudi Vision 2030. Journal of Health Informatics in Developing Countries, 12(1), 1- 11 .

Field, A. (2013) Discovering Statistics Using IBM SPSS Statistics: And Sex and Drugs and Rock "N" Roll, 4th Edition. Los Angeles, London, New Delhi: Sage.

Folger, R. (1993). Reactions to mistreatment at work. In K. Murnighan (Ed.), Social psychology in organizations: Advances in theory and research (pp. 161-183). Englewood Cliffs, NJ: Prentice Hall.

Fox, S., Spector, P. E., \& Miles, D. (2001). Counterproductive work behavior (CWB) in response to job stressors and organizational justice: Some mediator and moderator tests for autonomy and emotions. Journal of Vocational Behavior, 59(3), 291-309. http://doi.org/d998q4 Greenberg, J. (1984). On the apocryphal nature of inequity distress. In R. Folger (Ed.), The sense of injustice: 167-188. New York: Plenum.

Greenberg, J. (1986). Determinants of perceived fairness of performance evaluations. Journal of Applied Psychology, 71, 340-342.

Greenberg, J. (1990). Organizational justice: Yesterday, today, and tomorrow. Journal of Management, 16(2), 399-432.

Greenberg, J. (2004). Stress Fairness to Fare No Stress: Managing Workplace Stress by Promoting Organizational Justice. Organizational Dynamics, 33(4), pp. 352-359.

Greenberg, J. (2005). Managing Behavior in Organizations. Fourth Edition. Pearson Education, Inc. Published by Prentice Hall, 38-39.

Hair, J. F., Ringle, C. M., \& Sarstedt, M. (2014). PLS-SEM: Indeed a silver bullet. Journal of Marketing theory and Practice, 19(2), 139-152.

Hair, J.F., Hult, G.T.M., Ringle, C.M. and Sarstedt, M. (2017). A Primer on Partial Least Squares Structural Equation Modeling (PLSSEM), 2nd ed., Sage, Thousand Oaks, CA.

Hart, P.M. and Cooper, C. (2001). Occupational Stress: Toward a More Integrated Framework. In: Anderson, N., Ones, D.S., Sinangil, H.K. and Viswesvaran, C., Eds., Handbook of Industrial, Work \& Organizational Psychology, Vol. 2, Thousand Oaks: Sage Publications Ltd., 93-144. Houghton, J.D., Neck, C.P. and Kumar, K. S. (2016), The what, why, and how of spirituality in the workplace revisited: a 14-year update and extensión. Journal of Management, Spirituality and Religion, Vol. 13 No. 3, pp. 177-205

Ilyas, S., Abid, G., \& Ashfaq, F. (2020). Ethical leadership in sustainable organizations: The moderating role of general self-efficacy and the mediating role of organizational trust.
Sustainable Production and Consumption, Vol 22, pp. 195-20410.1016/j.spc.2020.03.003

Islam, M., \& Alharthi, M. (2020) Relationships among Ethical Commitment, Ethical Climate, Sustainable Procurement Practices, and SME Performance: An PLS-SEM Analysis. Sustainability, 12(23), 10168.https://doi.org/10.3390/su122310168 Jameel, A., Mahmood, Y. \& Jwmaa, S. (2020). Organisational Justice and Organisational Commitment among Secondary School Teachers. Cihan University-Erbil Journal of Humanities and Social Sciences. 4(1). 1-6. 10.24086/cuejhss.v4n1y2020.pp1-6.

Jaramillo, C., Rueda, M. \& Mora, G. (2006). Cenozoic Plant Diversity in the Neotropics. Science (New York, N.Y.). 311. 1893-6. 10.1126/science.1121380.

Jaramillo, F., Mulki, J. P. and Boles, J.S. (2013). Bringing Meaning to the Sales Job: The Effect of Ethical Climate and Customer Demandingness. Journal of Business Research, Vol 66(11), 2301-2307.

Joksimovic, L., Starke, D., Knesebeck, O., \& Siegrist, J. (2002). Perceived work stress, over commitment, and self-reported musculoskeletal pain: a cross-sectional investigation. Int $\mathbf{J}$ BehavMed, 9(2), 122-138.

Judge, T.A., and Colquitt, J.A. (2004). Organizational Justice and Stress: The Mediating Role of Work- Family Conflict. Journal of Applied Psychology, 89(3), 395-404.

Kancharla, R. and Dadhich, A. (2020). Perceived ethics training and workplace behavior: the mediating role of perceived ethical culture. European Journal of Training and Development, Vol. 45(1), pp. 53-73. https://doi.org/10.1108/EJTD-03-2020-0045

Kassim, K. M. A., Safizal, A. M., \& Fitri, M. M. (2018).The Mediating Role of Conflict Management Styles between Organizational Justice and Affective Commitment among Academic Staffs in Malaysian Public Universities. MATEC Web of Conferences, Vol. 150.

Keller, D. (1984). Humor as therapy. Wauwatosa, WI: Med-Psych Publications.https://www.amazon.com/HumorAs-Therapy-Daniel-Keller/dp/0897690826

Kline, R. B. (2011). Methodology in the Social Sciences. Principles and practice of structural equation modeling (3rd ed.). Guilford Press.

Kuenzi, M, Mayer, D.M, \& Greenbaum, R.L. (2019). Creating an ethical organizational environment: The relationship between ethical leadership, ethical organizational climate, and unethical behavior. Personnel Psychology, 1-29. https://doi.org/10.1111/peps.12356 
Kumasey, A. S., Bawole, J. N., \& Hossain, F. (2017). Organizational commitment of public service employees in Ghana: Do codes of ethics matter? International Review of Administrative Sciences, 83(1 Suppl), 59-77.

Lambert, E. G., Keena, L. D., Leone, M., May, D., \& Haynes, S. H. (2020). The effects of distributive and procedural justice on job satisfaction and organizational commitment of correctional staff. Social Science Journal, DOI: 10.1016/j.soscij.2019.02.002.

Lambert, E.G., Hogan, N.L., Griffin, M.L. (2007). The Impact of Distributive and Procedural Justice on Correctional Staff Job Stress, Job Satisfaction and Organizational Commitment. Journal of Criminal Justice, 35(6), 644-656.

Lee, S.J., Lee, J. H., Gillen, M \& Krause, N. (2014). Job Stress and Work-Related Musculoskeletal Symptoms Among Intensive Care Unit Nurses: A Comparison Between Job Demand-Control and Effort-Reward Imbalance Models. American journal of industrial medicine. 57. 10.1002/ajim. 22274.

Leventhal, G. S. (1980). What should be done with equity theory? New approaches to the study of fairness in social relationship. In K. J. Gergen, M. S. Greenberg, \& R. H. Willis (Eds.), Social exchange: Advances in theory and research (pp. 27-55). New York: Plenum.

Lind, E. A., \& Van den Bos, K. (2002). When fairness works: Toward a general theory of uncertainty management. In B. M. Staw\& R. M. Kramer (Eds.), Research in organizational behavior, Vol. 24, pp. 181-222. Boston: JAI Press.

Long, C., Li, Z., \& Ning, Z. (2015). Exploring the nonlinear relationship between challenge stressors and employee voice: The effects of leader-member exchange and organizationbased self-esteem. Personality and Individual Differences, 83, 24-30

Manville, C., El Akremi, A., Niezborala, M. and Mignonac, K. (2016), Injustice hurts, literally: the role of sleep and emotional exhaustion in the relationship between organizational justice and musculoskeletal disorders. Human Relations, Vol. 69(6), pp. 1315-1339.

Marshall, J., \& Cooper, C. (1979). Work experiences of middle and senior managers: The pressure and satisfaction. International Management Review, 19(1), 81-96.

Memon, M. A., Cheah, J. H., Ramayah, T., Ting, H., \& Chuah, F. (2018), Mediation analysis: Issues and recommendations. Journal of Applied Structural Equation Modeling, Vol. 2 No. 1, pp. i-ix
Memon, M.A., Salleh, R., Mirza, M.Z., Jun-Hwa, C., Ting, H. and Ahmed, M.S. (2019) "Performance appraisal satisfaction and turnover intention: the mediating role of work engagement", Management Decision, Vol. 58 No. 6, pp. 1053-1066.

Memon, M.A., Salleh, R., Mirza, M.Z., Cheah, J.-H., Ting, H., Ahmad, M.S. and Tariq, A. (2020), Satisfaction matters: the relationships between HRM practices, work engagement and turnover intention. International Journal of Manpower, Vol 42(1) https://doi.org/10.1108/IJM-04-2018-0127.

Memon, M.A., Ting, H., Cheah, J.H., Thurasamy, R., Chuah, F \& Cham, T.H (2019) Sample Size for survey research: review and Recommendations. Journal of Applied Structural Equation Modeling, 4(2), i-xx, 1-20.

Mitonga-Monga, J. (2020). Social exchange influences on ethical leadership and employee commitment in a developing country setting. Journal of Psychology in Africa, 30(6), 485-491. https://doi.org/10.1080/14330237.2020.1842587 Moorman, R. H. (1991). Relationship between organizational justice and organizational citizenship behaviors: Do fairness perceptions influence employee citizenship? Journal of Applied Psychology, 76(6), 845-855.

Moslehpour, M., Altantsetseg, P., Mou, W. \& Wong, W.K. (2018). Organizational Climate and Work Style: The Missing Links for Sustainability of Leadership and Satisfied Employees. 10.20944/preprints201810.0419.v1.

Mughal, Y. H (2020) A holistic model of organizational cynicism, cronyism and ingratiation. African Journal of Hospitality, Tourism and Leisure, 9(1), 1-12.

Mukhezakule, M. \& Tefera, O. (2019). The relationship between corporate strategy, strategic leadership and sustainable organisational performance: proposing a conceptual framework for the South African aviation industry. African Journal of Hospitality, Tourism and Leisure, 8(3), 1-19.

Mulki, J.P., Jaramillo, J.F. \& Locander, W.B. (2008). Effect of Ethical Climate on Turnover Intention: Linking Attitudinal- and Stress Theory. J Bus Ethics 78, 559-574 https://doi.org/10.1007/s10551-007-9368-6 Mulki, JP., Jaramillo, F., \& Locander, WB. (2006). Effects of ethical climate and supervisory trust on salesperson's job attitudes and intentions to quit. JPers Sell Sales Manage, Vol. 26(1), 19-26.

Niehoff, B.P and Moorman, R.H. (1993). Justice as a mediator of the relationship between methods of monitoring and organizational 
citizenship behavior. Academy of management journal, 36, (3), 527-556.

Omar, A., Salessi, S., Vaamonde, J., \& Urqueaga, F. (2018). Psychometric properties of Colquitt's Organizational Justice Scale in Argentine workers. Liberabit, 24(1), 61-79. doi: https://doi.org/10.24265/liberabit.2018.v24n1.0 5

Peuscher, D (2016). The resource orchestration theory as contributor to supply chain management: An assessment on its applicability. (Bachelor thesis), University of Twente, Twente. Prem, R., Scheel, T. E., Weigelt, O., Hoffmann, K., \& Korunka, C. (2018). Procrastination in daily working life: A diary study on within-person processes that link work characteristics to workplace procrastination. Frontiers in Psychology, 9, 1087-1097.

Qureshi, H., Frank, J., Lambert, E. G., Klahm, C., \& Smith, B. (2017). Organisational justice's relationship with job satisfaction and organisational commitment among Indian police. The Police Journal: Theory, Practice and Principles, 90(1), 3-23.

Rahman, A., Khan, M. F., Shahzad, N., Mustafa, K., \& Qurashi, F. (2016). Effects of organizational justice on organizational commitment. International Journal of Economics and Financial Issues, 6(3), 188-196.

Rasool, S.F., Wang, M., Zhang, Y., \& Samma, M. (2020) Sustainable Work Performance: The Roles of Workplace Violence and Occupational Stress. Int. J. Environ. Res. Public Health,17(3), 912. https://doi.org/10.3390/ijerph17030912

Roy, J.L., Bastounis, M., \& Minibas-Poussard, J. (2012) Interactional Justice and Counterproductive Work Behaviors: The Mediating Role of Negative Emotions. Social behavior and personality, Society for Personality Research, 40 (8), 1341-1355.

Schwepker, C.H. Jr. (2001). Ethical Climate's Relationship to Job Satisfaction, Organizational Commitment and Turnover in the Sales Force. Journal of Business Research, 54(1), p. 39-52.

Searle, B. J., \& Auton, J. C. (2015). The merits of measuring challenge and hindrance appraisals. Anxiety, Stress, and Coping, Vol 28(2), p. 121-143.

Sert, A., Elci, M., Uslu, T., \& Sener, I. (2014) The Effects of Organizational Justice and Ethical Climate on Perceived Work Related Stress. Procedia - Social and Behavioral Sciences Vol 150, $1187-1198$.

Shakil, R.M., Memon, M.A., \& Ting, H. (2021) Inclusive Leadership and Innovative work behavior: the mediating role of job autonomy.
Quality \& Quantity, https://doi.org/10.1007/s11135-021-01102-0

Sharma, P.K. and Kumra, R. (2020). Relationship between workplace spirituality, organizational justice and mental health: mediation role of employee engagement. Journal of Advances in Management Research, Vol. 17 No. 5, pp. 627-650. https://doi.org/10.1108/JAMR-01-2020-0007 Tadić, M., Bakker, A. B., \& Oerlemans, W. G. (2015). Challenge versus hindrance job demands and well - being: A diary study on the moderating role of job resources. Journal of Occupational and Organizational Psychology, 88(4), 702-725.

Takroni, H. A., Al-Hindi, A., Joshva, K., \& Al-Harbi, A. (2018).Job satisfaction among nurses in Al-Qassim hospitals and primary health care centers, Saudi Arabia, 2016.International Journal of Advanced Nursing Studies. 7(1). 34. 10.14419/ijans.v7i1.8864.

Tariq, B., Ali, M.S., Mughal, Y.H., \& Ali, T. (2018) Anticipated regret and moral norms in consumers' intention to select child labor restaurants: augmenting the theory of planned behavior. Amazonia Investiga, Vol 7(17), 505-519.

https://amazoniainvestiga.info/index.php/amazo nia/article/view/764

Teo, T.S.H., Srivastava, S.C. and Jiang, J.Y. (2008). Trust and electronic government success: an empirical study. Journal of Management Information Systems, Vol. 25(3), pp. 99-132.

Tepper, B. J. (2000).Consequences of abusive supervision. Academy of Management Journal, 43(2), 176-190.

Thibaut, J., \& Walker, L. (1975). Procedural justice: A psychological analysis. Hillsdale, NJ: Erlbaum.

Tuckey, M\& Searle, B. J., Boyd, C. M., \& Winefield, A. H. (2014). Hindrances Are Not Threats: Advancing the Multidimensionality of Work Stress. Journal of occupational health psychology. 20. 10.1037/a0038280.

Valentine, S \& Godkin, L. (2016). Ethics policies, perceived social responsibility, and positive work attitude. The Irish Journal of Management. 35. 10.1515/ijm-2016-0013.

Victor, B, \& Cullen, J.B. (1988). The organizational basis of ethical work climates, Administrative Science Quarterly, Vol. 3(1), pp. 101-125

Wood, S. J., \& Michaelides, G. (2016). Challenge and hindrance stressors and wellbeing-based work-nonwork interference: A diary study of portfolio workers. Human Relations, 69(1), 111-138. 